\title{
ANALISIS PENGARUH BEBAN USAHA DAN PENDAPATAN USAHA TERHADAP LABA PERUSAHAAN PADA PT. ARPENI PRATAMA OCEAN LINE Tbk.
}

\author{
Maulita $^{1)}$, M. Adham²), dan Amiril Azizah ${ }^{3)}$ \\ 1,2 Jurusan Kemaritiman, Politeknik Negeri Samarinda \\ ${ }^{3}$ Jurusan Administrasi Bisnis, Politeknik Negeri Samarinda \\ 1,2,3 Jl. Ciptomangunkusumo, samarinda, 75242 \\ E-mail : maulitamursandi@gmail.com ${ }^{1}$, adham@polnes.ac.id ${ }^{2)}$, amirilazizah@yahoo.com ${ }^{3)}$
}

\begin{abstract}
ABSTRAK
PT. Arpeni Pratama Ocean Line Tbk. Perusahaan yang mempunyai bisnis penyedia solusi transpotasi dan logisik terpadu, laporan keuangan berisi informasi mengenai pendapatan dan beban usaha selama satu priode akuntansi. Laporan ini merupakan tolak ukur keberhasilan perusahaan mengelola investasi yang telah ditanamkan oleh pihak investor. Penelitian ini menganalisa beban usaha dan pendapatan usaha jasa pada PT. Arpeni Pratama Ocean Line Tbk terhadap laba perusahaan. Penelitian ini bermanfaat sebagai bahan pertimbangan yang akan dihadapi perusahaan pada tahun 2019 dalam kebijakan moneter suku bunga tinggi dan sisi finansial pelayaran nasional dan juga sejumlah pajak yang membebani. Pengambilan sampel dalam penelitian ini menggunakan purposive sampling method. Jenis data penelitian ini adalah data sekunder yang diperoleh dari pengumpulan Annual Report (Laporan Keuangan) PT. Arpeni Pratama Ocean yang dimuat dalam IDX 2013 sampai dengan 2018. Metode yang digunakan untuk menganalisis adalah regresi linier berganda ditemukan bahwa pengaruh beban usaha terhadap laba usaha signifikan dan laba perusahaan dipengaruhi oleh beban usaha sebesar $36 \%$. Sedangkan pengaruh pendapatan usaha terhadap laba usaha perusahaan signifikan dan laba perusahaan dipengaruhi sebesar $12 \%$ dari pendapatan usaha.
\end{abstract}

Kata Kunci: Laporan Keuangan ,Beban Usaha, Laba Usaha, Pendapatan Usaha, Kebijakan moneter

\section{PENDAhuluan}

Pada saat ini poros maritime menjadi perhatian pemerintah Indonesia merupakan pangsa pasar dibidang maritime, seiring dengan kebijakan Tol laut maka arus transportasi dan pemenuhan kebutuhan maupun kebutuhan pembangunan menjadi hal utama, sehingga jasa transportasi laut menjadi potensi yang besar dalam mempengaruhi percepatan ekonomi.

Memasuki tahun 2019 ini industri pelayaran diharapkan dapat menopang pertumbuhan ekonomi nasional dengan cara mengangkut dan mendistribusikan barang ke berbagai penjuru daerah. Keberadaan transortasi laut sangat penting untuk mendistribusikan ke berbagai penjuru daerah karena dinilai lebih efesien dan efektif.

Sejumlah pihak menilai pertumbuhan industry pelayaran dinilai belum terlalu cemerlang di tahun 2019 karena masih berhadapan dengan beberapa tantangan. Tantangan tersebut antara lain, tantangan dalam kebijakan moneter suku bunga tinggi mencapai $12,25 \%$ sedangkan margin profit pelayaran masih satu digit di sisi fiscal pelayaran nasional juga masih dibebani sejumlah pajak yang antara lain seperti Pajak pertambahan NIlai (PPN) dan pembelian BBM pelaayran dalam Negeri. (Wijaya,2019).

PT. Arpeni Pratama Ocean Line Tbk. (APOL) merupakan perusahaan dengan bisnis penyedia solusi transportasi dan logistic terpadu yang pada saat ini memiliki 25 anak perusahaan dan 10 kantor cabang diberbagai daerah yang menjadi salah satu penopang perekonomian menghadapi tantang dalam kebijakan moneter dan kebijakan fiskal.

Untuk keberlangsungan perusahaan dan perputaran perekonomian perusahaan maka perusahaan harus memperhatikan biaya-biaya yang dikeluarkan dan pendapatan yang diterima oleh perusahaan, karena kedua hal tersebut dapat mempengaruhi laba perusahaan.

Laporan keuangan mempunyai peranan penting yang dapat digunakan oleh pihak manajemen perusahaan untuk mengetahui seberapa besar beban usaha terhadap laba perusahaan. Laporan keuangan untuk melihat hal terbut adalah laporan laba rugi.

Laporan laba rugi merupakan laporan keuangan yang didalamnya antara lain berisi informasi mengenai pendapatan dan beban selama satu periode akuntansi. Laporan laba rugi juga dapat dimanfaatkan oleh pihak manajemen sebagai tolak ukur keberhasilan perusahaan dalam mengelola investasi yang telah ditanamkan oleh pihak investor.

Analisis untuk mengetahui pengaruh beban usaha dan pendapatan usaha terhadap laba perusahaan sangat penting dilakukan agar perusahan dapat melakukan efisiensi karena perusahaan masih menanggung kewajiban sehingga diperlukan untuk mengantisipasi 
agar tidak memperbesar jumlah kewajiban yang masih harus dibayar perusahaan mampu menghadapi kebijakan moneter di industri pelayaran.

Beban operasional dan pendapatan usaha signifikan berpengaruh terhadap laba bersih perusahaan Food and beverage yang terdaftar di Bursa Efek Indonesia Periode 2010-2014 dengan menggunakan tingkat signifikansi 5\% dimana nilai R-Square yang diperoleh 97,69 dengan adjusted R-Square 97,01\% artinya $97,01 \%$ dipengaruhi oleh variabel yang diteliti dalam penelitian inni yaitu beban operasional dan pendapatan usaha terhadap laba bersih sedangkan $22,99 \%$ dipengaruhi variabel yang tidak diteliti dalam penelitian ini (Barus dkk, 2016)

Ramdhani (2015) menemukan bahwa harga jual berpengaruh positif signifikan terhadap laba bersih dan biaya operasional berpengaruh signifikan negatif terhadap laba bersih.

Efilia (2014) menemukan bahwa pendapatan usaha berpengaruh signifikan terhadap laba bersih sedangkan beban operasional tidak berpengaruh signifikan terhadap laba bersih sedangkan variabel pendapatan usaha dan beban operasional secara simultan berpengaruh signifikan terhadap laba bersih pada perusahaan kimia dan keramik, porselin dan kaca yang terdaftar di BEI periode 2008-2012.

Handayani (2016) hasil penelitiannya mengungkapkan laba perusahaan hanya dipengaruhi sebesar $0,0361 \%$ oleh biaya operasional sedangkan pendapatan jasa mempengaruhi sebesar $51 \%$ terhdap laba perusahaan.

Prakash, dkk (2016) All Cash is Not Created Equal: Detecting Fraudulent Cash Flows penelitian ini menunjukkan bahwa kenaikan net income dan aliran kas yang tinggi bukan menjadikan jaminan bagi investor atas kenaikan pada kas mungkin saja ada manipulasi pada transaksi

\section{RUANG LINGKUP}

Sedangkan Pada penelitian ini peneliti membatasi permasalahan bahwa pada penelitian ini menganalisa beban usaha dan pendapatan usaha jasa yang pada perusahaan PT. Arpeni Pratama Ocean Line Tbk. (APOL) terhadap laba perusahaan. Penelitian ini bermanfaat sebagai bahan pertimbangan dalam menghadapi tantangan yang dihadapi perusahaan pada tahun 2019 Tantangan tersebut antara lain, tantangan dalam kebijakan moneter suku bunga tinggi dan di sisi fiscal pelayaran nasional juga masih dibebani sejumlah pajak yang antara lain dan pembelian BBM pelayaran dalam Negeri. Sehingga dapat mengatur dengan baik perencanaan mengenai biaya yang harus ditanggung dan berapa pendapatan yang harus didapatkan agar laba perusahaan stabil.

\section{BAHAN DAN METODE}

Metode yang digunakan dalam penulisan ini adalah metode penelitian kuantitatif. Pengambilan sampel dalam penelitian ini dilakukan dengan pursosive sampling method, yaitu penentuan sampel atas dasar kesesuaian dan kriteria tertentu. Metode purposive sampling adalah metode pengumpulan sampel berdasarkan tujuan penelitian.

Jenis data penelitian ini adalah data sekunder yaitu data penelitian yang diperoleh dari pengumpulan Annual Report (Laporan keuangan) PT. Arpeni Pratama Ocean tbk yang dimuat dalam IDX 2013-2018. Metode yang digunakan untuk menganalisis data dalam penelitian ini menggunakan regresi linier berganda.

\subsection{Pengertian Beban/Biaya}

Mulyadi (2015) "Biaya adalah pengorbanan sumber ekonomis yang diukur dalam satuan uang, yang telah terjadi atau yang kemungkinan akan terjadi untuk tujuan tertentu.

Manurut Hery (2013) beban adalah arus keluar aktiva atau penggunaan lainnya atas aktiva atau terjadinya (munculnya) kewajiban entitas (atau kombinasi dari keduanya) yang disebabkan oleh pengiriman atau pembuatan barang, pemberian jasa, atau aktivitas lainnya yang merupakan operasi utama atau operasi sentral perusahaan.

Kemudian Baldric, dkk (2013) memberikan pengertian bahwa biaya adalah pengorbanan sumber ekonomi untuk memperoleh barang atau jasa yang diharapkan member manfaat sekarang atau masa yang akan datang.

\subsection{Pengertian Pendapatan}

Menurut Hery (2013) pendapatan adalah arus masukkan dari aktiva atau peningkatan yang lain dari aktiva atau penyelesaian suatu kewajiban entitas atau kombinasi dari keduanya mulai dari pengiriman barang, pemberian jasa, atau aktiva lainnya yang merupakan kegiatan operasi utama dari perusahaan.

Sedangkan putra (2012) menyebutkan bahwa pendapatan adalah arus masuk atau peningkatan lainnya atas aktiva sebuah entitas atau penyelesaian kewajiban (atau kombinasi dari keduanya) selama satu periode dari pengiriman atau produksi barang, penyediaan jasa, atau aktivitas lain yang merupakan operasi utama atau sentral entitas yang sedang berlangsung. Sumarni dan Jhon (2014) pendapatan adalah jumlah uang yang dibayarkan kepada sipenerima dari pendapatan tersebut.

Dalam pengertian ini pendapatan yang diperoleh dari transaksi penyerahan barang atau jasa atau aktivitas usaha lainnya itu adalah yang berhubungan secara langsung dengan kegiatan untuk memperoleh laba usaha yang dapat mempengaruhi terhadap jumlah ekuitas pemilik. Dengan demikian, tidak termasuk dalam pengertian pendapatan, adalah peningkatan aktiva perusahaan yang timbul dari pengadaan aktiva, investasi 
oleh pemilik, pinjaman ataupun koreksi laba rugi pada periode sebelumnya

\subsection{Pengertian Laba}

Setiap perusahaan berusaha untuk memperoleh laba yang maksimal. Laba yang diperoleh perusahaan akan berpengaruh terhadap kelangsungan hidup perusahaan tersebut. Berikut pengertian laba menurut beberapa ahli:

L.M. Samryn (2012), menyatakan bahwa pengertian laba adalah sebagai berikut: "Laba merupakan sumber dana internal yang dapat diperoleh dari aktivitas normal perusahaan yang tidak membutuhkan biaya ekstra untuk penyimpanan dan pengguanannya".

Sedangkan menurut Wild dan Subramanyam (2014), menyatakan bahwa pengertian laba adalah sebagai berikut: "Laba (earnings) atau laba bersih (net income) mengindikasikan profitabilitas perusahaan. Laba mencerminkan pengembalian kepada pemegang ekuitas untuk periode bersangkutan, sementara pos-pos dalam laporan merinci bagaimana laba didapat".

Berdasarkan pengertian di atas dapat disimpulkan bahwa laba adalah kelebihan pendapatan di atas biaya sebagai imbalan menghasilkan barang dan jasa selama satu periode akuntansi

Akuntansi yang memiliki konsep perhitungan laba memiliki perbedaan pandangan dalam menghitung laba (income). Menurut Harahap (2011) menyimpulkan empat pendapat yaitu

1. Pemikiran klasik yang ber pedoman pada postulat unit of measure (satuan ukur) dan prinsip historikal cost yang sering disebut historical cost acounting atau convensional accounting sebagaimana kita percayai saat ini, yang dinamakan konsep laba accounting income.

2. Pemikiran neo klasik yang mengubah postulat unit of measure dengan menerapkan perhitungan perubahan $\mathrm{t}$ ingkat harga umum (general price level) dan tetap mempertahankan prinsip Historical cost, yang di kenal dengan istilah general price level adjusted historical cost acounting, dan perhitungan labanya di sebut GPLA accounting income.

3. Pemikiran radikal yang memilih harga sekarang (curent value) sebagai dasar penilaian bukan historical cost lagi, dimana konsep ini di kenal dengan current value accounting, sedangkan perhitungan labanya disebut Curent income.

4. Pemikiran neo radikal yang menggunakan current value, tetapi disesuaikan dengan perubahan tingkat harga umum, yang di sebut GPLA curent accounting, sedangkan perhitungan labanya disebut adjusted current income.

\section{PEMBAHASAN}

Didalam penelitian ini terdapat 3 varibel yaitu beban usaha yang merupakan variabel bebas, pendapatan usaha yang merupakan variabel control dan laba usaha yang merupakan variabel dependen atau variabel terikat. Sebelum dilakukan pengujian statistik maka terlebih dahulu ditampilkan data beban usaha, pendapatan usaha dan laba usaha selama periode 2012-2018.

\subsection{Beban Usaha}

Di dalam penelitian ini variabel bebas adalah beban usaha, data yang diambil adalah data beban usaha selama periode 2012-2018, berikut adalah beban usaha pada perusahaan PT. Arpeni Pratama Ocean Line Tbk. (APOL) yang penulis disajikan pada tabel 1

\section{Tabel 1. Beban Jasa (dalam Miliar Rupiah)}

\begin{tabular}{|c|c|}
\hline Tahun & Jumlah beban usaha \\
\hline 2012 & Rp 1.647 .585 \\
\hline 2013 & Rp 1.420 .585 \\
\hline 2014 & Rp 833.596 \\
\hline 2015 & $\operatorname{Rp~} 632.937$ \\
\hline 2016 & RP 361.007 \\
\hline 2017 & $\operatorname{Rp~} 368.646$ \\
\hline 2018 & $\operatorname{Rp} 328.023$ \\
\hline
\end{tabular}

Sumber: Laporan Beban Jasa Perusahaan PT. APOL

Berdasarkan tabel diatas makan pada tahun 2012 sampai dengan tahun 2018 setiap tahun jumlah beban usaha yang ditanggung oleh PT. Arpeni Ocean Line Tbk mengalami penurunan. Hal ini juga dapat terlihat jelas dengan diagram beban jasa yang yang memperlihatkan bahwa selama 7 tahun yaitu periode

2012 sampai dengan 2018 terlihat penurunan yang cukup signifikan yang penulis sajikan pada gambar 1

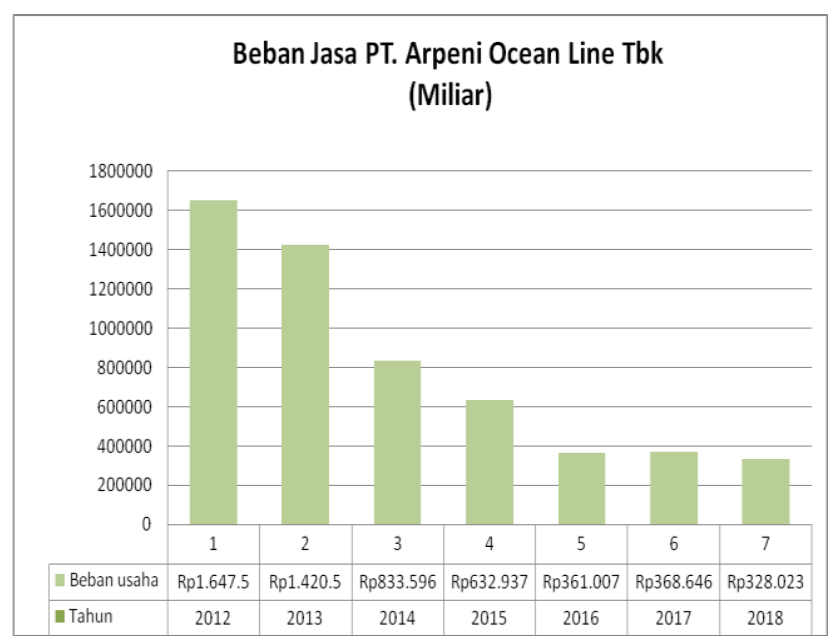

Gambar 1. Diagram Beban Jasa

Sumber: Laporan Beban Jasa Perusahaan PT. APOL 


\subsection{Pendapatan Jasa}

Pendapatan jasa di dalam penelitian ini adalah sebagai variabel control. Data pendapatan jasa diambil selama periode tahun 2012-2018, berikut adalah data pendapatan jasa yang penulis sajikan pada tabel 2

Tabel 2. Pendapatan Jasa (dalam Miliar Rupiah)

\begin{tabular}{|c|c|}
\hline Tahun & Jumlah Pendapatan \\
\hline 2012 & Rp 1.176 .954 \\
\hline 2013 & Rp 1.100 .167 \\
\hline 2014 & Rp 824.638 \\
\hline 2015 & Rp 663.386 \\
\hline 2016 & Rp 410.223 \\
\hline 2017 & Rp 466.982 \\
\hline 2018 & Rp 463.530 \\
\hline
\end{tabular}

Sumber: Laporan Pendapatan Jasa Perusahaan PT. APOL

Berdasarkan tabel diatas makan pada tahun 2012 sampai dengan tahun 2018 setiap tahun jumlah Pendapatan Jasa yang diterima oleh PT. Arpeni Ocean Line Tbk mengalami penurunan. Hal ini juga dapat terlihat jelas dengan diagram Pendapatan Jasa yang yang memperlihatkan bahwa selama 7 tahun yaitu periode 2012 sampai dengan 2018 terlihat terjadi penurunan signifikan pada tahun 2016 kemudian ditahun 2017 mengalami kenaikan, tetapi pada tahun 2018 kembali mengalami penurunan seperti yang penulis sajikan pada gambar 2

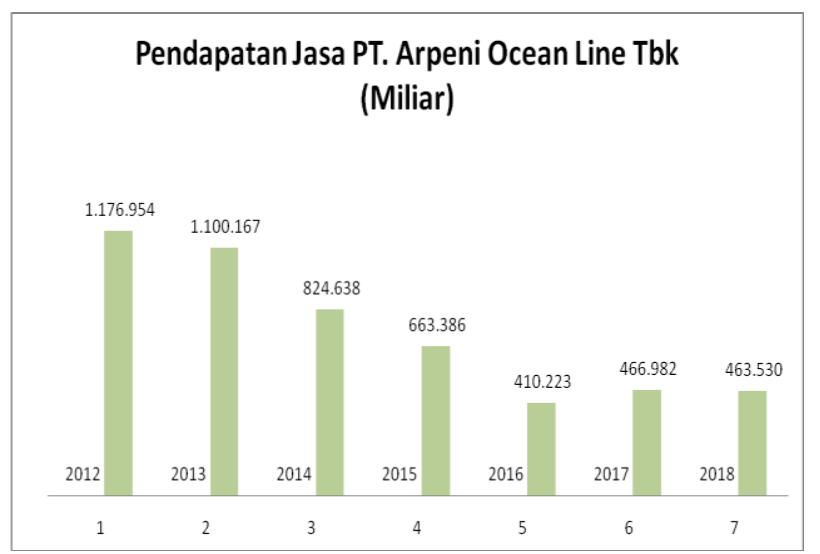

Gambar 2. Diagram Pendapatan Jasa

Sumber: Laporan Pendapatan Jasa Perusahaan PT. APOL

\subsection{Laba Jasa Perusahaan}

Laba jasa pelayaran dalam penelitian ini disebut juga sebagai variabel dependen atau variabel terikat. Laba jasa pelayaran pada PT. Arpeni Ocean Line Tbk. Data laba diambil selama 7 priode yaitu tahun 2012 2018, yang penulis sajikan pada tabel 3

Tabel 3. Laba Jasa perusahaan (Dalam Miliar Rupiah)

\begin{tabular}{|c|c|}
\hline Tahun & Laba Jasa Perusahaan \\
\hline 2012 & $-\operatorname{Rp} 470.631$ \\
\hline 2013 & $-\operatorname{Rp} 320.418$ \\
\hline 2014 & $-\operatorname{Rp} 8.948$ \\
\hline 2015 & $\operatorname{Rp} 30.958$ \\
\hline 2016 & $\operatorname{Rp} 49.216$ \\
\hline 2017 & $\operatorname{Rp} 98.336$ \\
\hline 2018 & $\operatorname{Rp} 135.507$ \\
\hline
\end{tabular}

Sumber: Laporan Pendapatan Jasa Perusahaan PT. APOL

Berdasarkan tabel diatas, pada tahun 2012 sampai dengan 2014 perusahaan mengalami kerugian. Pada tahun 2015 perusahaan mendapatkan laba dan semakin meningkat sampai pada tahun 2018.

\section{Laba Usaha PT. Arpeni Ocean Line Tbk} (Miliar)

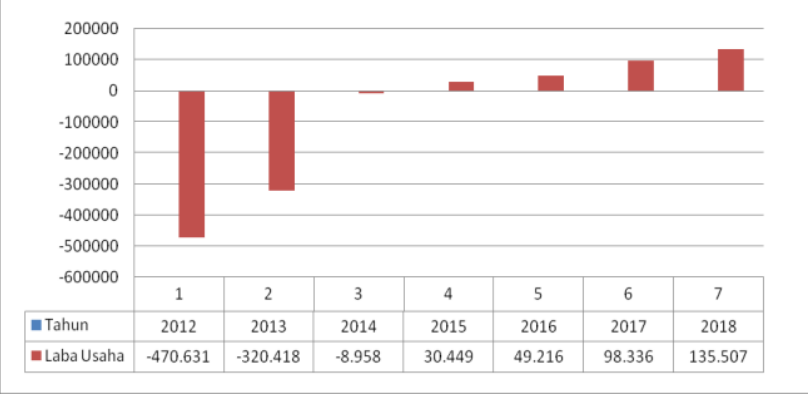

Gambar 3. Diagram Laba Jasa Perusahaan Sumber: Laporan Pendapatan Jasa Perusahaan PT. APOL 
Tabel 4. Tabel Penolong

\begin{tabular}{|c|c|c|c|c|c|c|c|c|c|}
\hline Tahun & $\mathbf{X 1}$ & $\mathbf{X 2}$ & $\mathbf{Y}$ & $\mathbf{( X 1}^{\mathbf{2}}$ & $\mathbf{( X 2}^{\mathbf{2}}$ & $(\mathbf{Y})^{\mathbf{2}}$ & $\mathbf{X 1 . Y}$ & $\mathbf{X 2 . Y}$ & $\mathbf{X 1 . X 2}$ \\
\hline 2012 & 14,31 & 13,98 & 13,06 & 204,78 & 6,96 & 6,60 & 186,9778 & 182,584 & 200,0989 \\
\hline 2013 & 14,17 & 13,91 & 12,68 & 200,79 & 6,93 & 6,45 & 179,5951 & 176,3547 & 197,0709 \\
\hline 2014 & 13,63 & 13,62 & 9,10 & 185,78 & 6,82 & 4,88 & 124,069 & 123,9707 & 185,7251 \\
\hline 2015 & 13,36 & 13,41 & 10,32 & 178,49 & 6,74 & 5,45 & 137,9067 & 138,3918 & 179,0672 \\
\hline 2016 & 12,80 & 12,92 & 10,80 & 163,84 & 6,55 & 5,66 & 138,2547 & 139,6355 & 165,3898 \\
\hline 2017 & 12,82 & 13,05 & 11,50 & 164,35 & 6,60 & 5,97 & 147,3529 & 150,0712 & 167,3214 \\
\hline 2018 & 12,70 & 13,05 & 11,82 & 161,29 & 2,57 & 6,10 & 150,083 & 154,1691 & 165,7031 \\
\hline
\end{tabular}

\subsection{Pengujian Statistik}

Uji statistik dilakukan untuk mengetahui apakah sebaran data laporan keuangan dalam penelitian ini memenuhi asumsi normalitas. Dalam data penelitian ini sebaran nilai memiliki nilai yang berpusat dinilai ratarata dan frekuensi keluarnya nilai data semakin kecil apabila nilai data semakin ekstrim. Uji normalitas menggunakan SPSS versi 22 untuk variabel beban usaha, pendapatan usaha dan laba perusahaan ditunjukkan dengan gambar 4

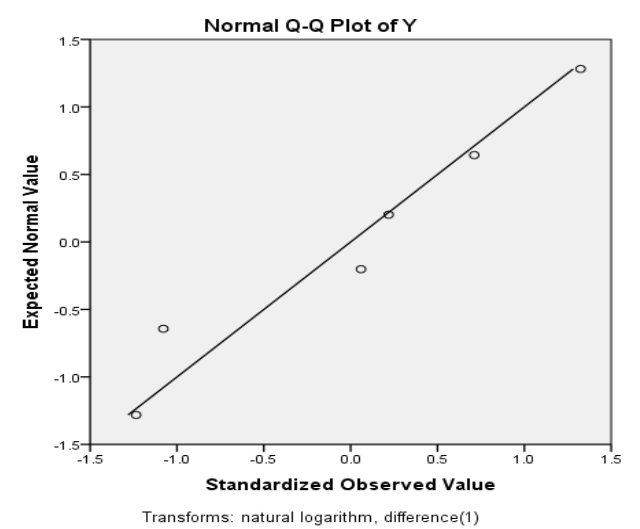

Gambar 4. Uji Normalitas

Hasil output histogram menunjukkan pola distribusi normal, seperti yang telihat grafik normal menunjukkan pola penyebaran titik-titik disekitar garis diagonal, mengikuti arah garis diagonal mengindikasi model regresi memenuhi asumsi normalitas.

\subsection{Pengaruh Beban Usaha Terhadap Laba Usaha Perusahaan}

\section{Uji Koefisein Korelasi}

Pengujian Koefisien korelasi dalam penelitian ini bertujuan mengetahui seberapa besar hubungan kedua variabel tersebut. Berdasarkan uji ini maka ditemukan bahwa terdapat hubungan antara beban usaha dan laba usaha perusahaan sebesar 0,367 dan positif pembulatan jumlah dalam persentase $4 \%$. Sifat korelasi positif menunjukkan semakin tinggi beban maka laba juga meningkat dalam situasi tertentu. Sedangkan nilai $r$ hitung sebesar 0,418 berarti hubungan tersebut signifikan atau diterima dengan probabilitas dibulatkan $42 \%$.

\section{Uji Koefisien Determinasi}

Kekuatan pengaruh beban usaha terhadap laba usaha perusahaan dapat diketahui dari besarnya nilai koefesien determinasi (R2) yang berada diantara nol dan satu. Hasil data yang diolah penulis menggunakan SPSS versi 22 di tunjukkan pada tabel 6

Tabel 5. Uji Koefisien Dterminasi

Analisa Koefisien Determinasi Model Summaryb

\begin{tabular}{|l|l|l|l|}
\hline & & $\begin{array}{l}\text { Beban } \\
\text { Usaha }\end{array}$ & Laba \\
\hline Beban & Pearson & 1 & 0,367 \\
Usaha & $\begin{array}{l}\text { Correlation } \\
\text { Sig. (2-tailed) }\end{array}$ & 7 & 0,417 \\
& N & & \\
\hline Laba & Pearson & 0,367 & 1 \\
& Correlation & 0,418 & \\
& Sig. (2-tailed) & 7 & 7 \\
& N & & \\
\hline
\end{tabular}

a. Predictors: (Constant), beban usaha

b. Dependent Variable: Laba Usaha Sumber: Output SPSS 22

Dari tabel tersebut maka dapat dilihat bahwa nilai $\mathrm{R}$ square (angka korelasi yang di kuadratkan atau 0,367 ${ }^{2}$ ) sebesar 0,135 sama dengan 13,5\%. Berdasarkan angka tersebut maka artinya laba usaha perusahaan dipengaruhi $13,5 \%$ dari beban usaha, sedangkan sisanya $86,50 \%$ dipengaruhi oleh factor lain. 


\section{Uji persamaan Regresi Liner}

Pengujian ini dilakukan untuk menentukan model regresi pengaruh beban usaha terhadap laba perusahaan pelayaran, sehingga kita dapat meramalkan bagaiman a tingkat laba perusahaan.

\section{Analisis Regresi Linier Berganda}

Pengujian ini dilakukan untuk menentukan model regresi pengaruh pendapatan jasa terhadap laba perusahaan pelayaran, sehingga kita dapat meramalkan bagaimana tingkat laba perusahaan pelayaran.

Dari model regresi maka diperoleh konstanta (B) adalah 116,986 dengan tanda negatif dan koefisien sebesar 0,758 bertanda positif, yang berarti bahwa apabila beban usaha naik maka laba akan turun. Selain itu nilai signifikansi yang dimiliki sebesar 0,418 dimana nilai ini lebih kecil dari 0,758 maka Ho ditolak dan H1 diterima.karena tingkat signifikansi kurang dari 0,758 maka pengaruh beban usaha terhadap laba usaha perusahaan signifikan. Pengaruh pendapatan Usaha Terhadap Laba Usaha Perusahaan perusahaan PT. Arpeni Pratama Ocean Line Tbk. Seperti yang ditunjukkan dalam tabel 6

Tabel 6. Model Regresi

\begin{tabular}{|c|c|c|c|c|c|c|}
\hline \multicolumn{7}{|c|}{ Coefficients $^{\mathrm{a}}$} \\
\hline \multirow[b]{2}{*}{ Model } & & \multicolumn{2}{|c|}{$\begin{array}{l}\text { Unstandardized } \\
\text { Coefficients }\end{array}$} & \multirow{2}{*}{$\begin{array}{l}\text { Standardiz } \\
\text { ed } \\
\text { Coefficien } \\
\text { ts } \\
\text { Beta }\end{array}$} & & \multirow[b]{2}{*}{ Sig. } \\
\hline & & B & \begin{tabular}{|l} 
Std. \\
Error
\end{tabular} & & & \\
\hline \multirow[t]{2}{*}{1} & $\begin{array}{l}\text { (Cons } \\
\tan t)\end{array}$ & -116.986 & $\begin{array}{l}1152.62 \\
8\end{array}$ & & .101 & .034 \\
\hline & $\mathrm{X} 1$ & .758 & .859 & .367 & .882 & .418 \\
\hline
\end{tabular}

a. Dependent Variable: Laba

\section{Analisis Regresi Linier Sederhana}

Dari model regresi diatas diperoleh kontanta (B) adalah 326.625 dengan tanda positif. Dan koefisien sebesar 1,087 bertanda positif, artinya bila pendapatan naik maka laba akan naik pada kondisi tertentu. Selain itu, nilai signifikansi yang yang dimiliki adalah sebesar 0,454 dimana nilai ini lebih kecil dari 1,087 maka Ho ditolak dan H1 diterima. Karena tingkat signifikansinya kurang dari 1,087 maka pengaruh pendapatan terhadap laba signifikan.

\section{Pengaruh Faktor Lain Terhadap Laba Perusahaan}

Analisis pada penelitian ini mempunyai tujuan untuk mengetahui seberapa besar banyak faktor lain yang mempengaruhi laba. Dari hasil analisis perhitungan antara beban usaha terhadap laba usaha dengan menggunakan uji koefiesien determinasi 0,367 sama dengan $36,7 \%$ dimana angka tersebut mempunyai arti bahwa laba perusahaan dipengaruhi sebesar $36,7 \%$ oleh bebah usaha, sedangkan sisnya sebesar 63,3\% dipengaruhi oleh faktor lain.

Sedangkan pendapatan usaha terhadap laba usaha dengan menggunakan uji determinasi ditemukan bahwa angka koefiseien determinasi sebesar 0,116 sama dengan $11,6 \%$ dengan pembulan 12\%. Angka tersebut berarti bahwa laba perusahaaan pelayaran hanya dipengaruhi $12 \%$ dipengaruhi pendapatan usaha sedangkan nilainya $88 \%$ dipengaruhi faktor lain.

Besarnya faktor lain yang muncul mengidentifikasikan bahwa pengaruh terhadap laba perusahaan tidak hanya terjadi akibat beban usaha dan pendapatan usaha saja. nilai signifikansi yang dimiliki sebesar 0,818 dimana nilai ini lebih kecil dari 0,758 maka Ho ditolak dan H1 diterima.karena tingkat signifikansi kurang dari 0,758 maka pengaruh beban usaha terhadap laba usaha perusahaan signifikan. Pengaruh pendapatan Usaha Terhadap Laba Usaha Perusahaan perusahaan PT. Arpeni Pratama Ocean Line Tbk. Selain itu, nilai signifikansi yang yang dimiliki adalah sebesar 0,454 dimana nilai ini lebih kecil dari 1,087 maka Ho ditolak dan H1 diterima. Karena tingkat signifikansinya kurang dari 0,141 maka pengaruh pendapatan terhadap laba signifikan.

\section{KESIMPULAN}

Berdasarkan uji koefesien determinasi diketahui bahwa beban usaha dan pendapatan usaha berpengaruh terhadap laba usaha perusahaan. Hasil pengujian menunjukkan bahwa beban usaha merupakan variabel yang berpengaruh paling banyak terhadap laba perusahaan dan dari hasil analisis diketahui bahwa laba perusahaan semakin meningkat dari tahun 2012 sampai 2018 salah satu faktor yang mempengaruhi adalah penurunan jumlah beban usaha perusahaanPenelitian ini sejalan penelitian (Barus, dkk, 2016 ) dimana Beban operasional dan pendapatan usaha signifikan berpengaruh terhadap laba bersih perusahaan Food and beverage yang terdaftar di Bursa Efek Indonesia Periode 2010-2014. Namun Hasil Penelitian ini tidak sejalan dengan penelitian Handayani (2016) yang mana hasil penelitiannya mengungkapkan laba perusahaan secara signifikan dipengaruhi oleh pendapatan sedangkan biaya operasional tidak berpengaruh secara signifikan terhdap laba perusahaan. Perbedaan ini dikarenakan bahwa sampel yang diambil adalah industri yang berbeda sehingga berbeda kebijakan moneter dan pembebanan biaya yang harus ditanggung perusahaan.

\section{SARAN}

PT. Arpeni Pratama Ocean Line Tbk harus benarbenar memperhitungkan beban usaha yang dikeluarkan perusahaan khususnya terkait dengan kebijakan moneter pada industri pelayaran yang kurang bersahabat ditahun 2019. Beban seperti pajak PPN dan pembelian BBM dalam negeri serta biaya logistik yang harus ditekan, karena akan memberikan beban terhadap profit margin 
perusahaan. Kebijakan pemerintah mengenai Pendataan berkala jumlah, ukuran dan jenis kapal juga menjadi tantangan bagi perusahaan dari segi pembiayaan.

\section{DAFTAR PUSTAKA}

Ahmad Wijaya.2019. Prospek Industri Pelayaran Nasional 2019, Neraca.co.id www.neraca.co.id/article/112098/prospekindustri-pelayaran-nasional-di-2019

Barus,dkk.2016. Analisis Pengaruh Beban Operasional pada Pendapatan Usaha dan Dampaknya Terhadap Laba Bersih (Studi Kasus pada Perusahaan Food and Beverage yang terdaftar di Bursa Efek Indonesia Periode 2010-2014). Confrence on Management and Behavioral Studies.2-ISSN No: 2541-2850

Blocher, Edward J, David E, Stout, dan Garry Cokins. 2010. Manajemen Biaya: Penekanan Strategis. Penerjemah M. Yusuf Hamdan dan M. Ramdan Adhi. Jakarta: Salemba Empat.

Deo,O. dan Liu,C.Z.2016. All Cash is Not Created Equal: Detecting Fraudulent Cash Flows. Journal of Forensic \& Investigative Accounting Volume 8: Issue 2. Special Issue.

Efilia,M .2014. Pengaruh Pendapatan Usaha dan Beban OPerasional Terhadap Laba Bersih pada Perusahaan Kimia dan Keramik, Porselin \& Kaca yang Terdaftar di Bursa Efek Indonesia Periode 2008-2012. e- Journal. Fakultas Ekonomi Universitas Maritim Raja Ali Haji.

Handayani, M. 2016. Analisa Biaya Operasional dan Pendapatan Jasa Terhadap Perusahaan pada PT. BHL,KNIT-2 Nusa Mandiri, 37-46.
Hery. 2013. Akuntansi Keuangan Menengah.CAPS (Central of Academic Publishing Service). Yogyakarta.

Mulyadi. 2015. Akuntansi Biya Edisi 5. SEkolah Tinggi Ilmu Manajemen YKPN.

Mulyadi. 2014. Akuntansi Biaya. Edisi 5. Aditya Media: Yogyakarta.

Mulyadi, 2014, Akuntansi Biaya, Edisi kelima, UPP STIM YKPN, Yogyakarta.

Ramdhani, B. 2015. Pengaruh Harga Jual dan Biaya Operasional Terhadap Laba Bersih pada perusahaan Tambangan Sub Sektor Batubara yang Terdaftar di Bursa Efek Indonesia Periode 20102013. Skripsi. Jurusan Akuntansi Fakultas Ekonomi Universitas Komputer Indonesia.

Samryn,L.L. 2012. Akuntansi Manajemen Informasi Biaya Untuk Mengendalikan Aktivitas Operasi dan Investasi. Edisi Pertama. Jakarta: Kencana Prenada Media Group.

Subramanyam \& Wild .. 2014. Analisis Laporan Keuangan. Edisi 10: Salemba 4

Supriyono, R 2011. Akuntansi Biaya, Perencanaan dan Pengendalian biaya, serta pengambilan keputusan. Yogyakarta: BPFE

Siregar, Baldric, Bambang Supripto, Dody Hapsoro, Eko Widodo, Frasto Biyanto. 2013. Akuntansi Manajemen. Jakarta: Salemba Empat.

Siregar Baldric, Suripto Bambang dkk. 2013. Akuntansi Manajemen. Salemba Empat. Jakarta

\section{UCAPAN TERIMA KASIH}

Penulis mengucapkan kepada pihak Politeknik Negeri Samarinda yang mendukung penelitian ini dan mahasiswa yang terlibat dalam penelitian ini. 